\title{
Penggunaan Media dalam Pembelajaran bahasa Indonesia pada Siswa SMA
}

\author{
Suci Lestari
}

\section{4}

\section{Sucilestari27052001@gmail.com}

Salah satu faktor keberhasilan dalam pembelajaran adalah faktor kemampuan guru dalam merencanakan dan melaksanakan pembelajaran. Kegiatan pembelajaran yang efektif tidak dapat muncul dengan sendirinya, tetapi guru harus menciptakan pembelajaran yang memungkinkan siswa mencapai tujuan pembelajaran yang telah ditetapkan. Oleh karena itu, dibutuhkan proses penyampaian informasi yang optimal dalam pembelajaran. Salah satu upaya agar terciptanya kondisi tersebut adalah pemanfaatan media pembelajaran yang optimal.

Media merupakan segala sesuatu yang dapat menyalurkan pesan, merangsang pikiran, perasaan dan kemauan siswa sehingga mendorong terjadinya proses belajar pada dirinya. Media pendidikan adalah seperangkat alat bantu atau pelengkap yang digunakan oleh guru atau pendidik dalam rangka berkomunikasi dengan siswa atau peserta didik (Suhatman Jaya, Syahrul $\mathrm{R}$, 2013). Dalam pembelajaran bahasa Indonesia media dapat mengoptimalkan proses pembelajaran. Penggunaan media juga dapat membuat pembelajaran menjadi menyenangkan. Sebagaimana penelitian oleh (Syofiani et al., 2019) yang menyatakan media teka-teki silang dipandang dapat meningkatkan keterampilan berbahasa siswa dan siswa merasa senang dan bersemangat untuk mengikuti pembelajaran.

Dalam pembelajaran bahasa Indonesia, penggunaan media juga sangat berperan dalam peningkatan keterampilan berbahasa yaitu menyimak, berbicara, membaca, dan menulis. Oleh sebab itu, pembelajaran keterampilan berbahasa di sekolah tidak hanya menekankan pada aspek teori saja, tetapi bagaimana agar siswa mampu menggunakan bahasa sebagaimana fungsinya. Beberapa penelitian berikut pentingnya penggunaan media dalam meningkatkan keterampilan berbahasa. Penelitian pada tahun 2013 oleh (Handayani et al., 2013) yang menyatakan penggunaan media lagu dalam pembelajaran keterampilan menulis puisi siswa kelas IX SMP N 5 Lubuk Basung sangat berperan penting dalam mewujudkan keterampilan siswa dalam menggunakan citraan dan majas dalam puisi. Penelitian selanjutnya pada tahun 2016 oleh (Fitri et al., 2016) keterampilan menulis karangan argumentasi siswa kelas X SMA Negeri 5 Padang sebelum menggunakan model pembelajaran kooperatif tipe TTW berbantuan media gambar lebih rendah daripada keterampilan menulis karangan argumentasi siswa kelas X SMA Negeri 5 Padang sesudah menggunakan model pembelajaran kooperatif tipe TTW berbantuan media gambar. Penelitian selanjutnya pada tahun 2019 oleh (Syofiani et al., 2019) dan (Putri \& R., 2019) yang menyatakan terdapat pengaruh yang signifikan dalam penggunaan model 
pembelajaran kooperatif tipe think talk write berbantuan media audiovisual terhadap keterampilan menulis teks persuasi siswa kelas VIII SMP Negeri 8 Padang.

Mengingat perlunya penggunaan media dalam pembelajaran bahasa Inggris Indonesia, penulis melakukan sebuah survei tentang penggunaan media pembelajaran dalam pelajaran bahasa Indonesia. Survei ini disebarkan melalui google form dengan responden 30 orang siswa SMA Negeri 2 Kota Sawahlunto yang terdiri dari siswa kelas X dan XII. Survei ini berisi 10 pernyataan yang tentang penggunaan media pembelajaran dalam pelajaran bahasa Indonesia.

Pernyataan pertama adalah penggunaan media dalam pembelajaran bahasa Indonesia sangat penting. Hasilnya adalah 46,7\% menyatakan sangat setuju dan 53,3\% menyatakan setuju. Dari hasil survei tersebut penulis menyimpulkan bahwa penggunaan media dalam pembelajaran bahasa Indonesia sangat penting. Hal ini sejalan dengan pendapat (Novelti et al., 2018) yang menyatakan bahasa memiliki peran sentral dalam perkembangan intelektual, sosial, dan emosional peserta didik. Bahasa merupakan penunjang keberhasilan dalam belajar. Pendapat ini ditegaskan oleh Mone dalam (Novelti et al., 2018) yang menyatakan pembelajaran bahasa diharapkan dapat membantu peserta didik mengenal dirinya sendiri, budayanya, dan orang lain. Selain itu, bahasa digunakan untuk mengungkapkan ide dan perasaan, berpartisipasi dalam masyarakat, menemukan dan menggunakan kemampuan analitis dan imajinatif mereka sendiri. Pendapat tersebut menunjukkan betapa pentingnya kedudukan bahasa, sehingga diperlukan media yang efektif dalam penyampaian pembelajaran bahasa itu.

Pernyataan kedua adalah guru telah menggunakan media pembelajaran yang sesuai dengan materi pelajaran bahasa Indonesia yang diajarkan. Hasilnya adalah 13,3\% menyatakan sangat setuju, 83,3\% menyatakan setuju, dan 3,4\% menyatakan kurang setuju. Dari hasil survei tersebut penulis dapat menyimpulkan bahwa guru telah menggunakan media yang sesuai dalam pembelajaran bahasa Indonesia. Menurut Saud (2009: 97) media yang tepat guna, berdaya guna, dan bervariasi dapat menjadi suatu media pembelajaran yang baik. Isi media yang dirancang sesuai dengan desain pembelajaran dapat menjadikan media berkualitas. Media yang berkualitas akan menumbuhkan ketertarikan bagi peserta didik untuk belajar menggunakan media.

Pernyataan ketiga adalah media pembelajaran telah digunakan dalam pembelajaran keterampilan menyimak, membaca, membaca, dan menulis. Hasilnya adalah 10\% menyatakan sangat setuju,83,3\% menyatakan setuju, dan 6,7\% menyatakan kurang setuju. Dari hasil survei tersebut penulis menyimpulkan bahwa media telah digunakan dalam keterampilan berbahasa. Hal ini sesuai dengan tujuan pembelajaran bahasa Indonesia pada kurikulum 2013 secara umum bertujuan agar siswa mampu menguasai enam keterampilan, yaitu keterampilan menyimak, membaca, memirsa, berbicara, menulis dan menyaji (Suhatman Jaya, Syahrul R, 2013). Contohnya dalam kurikulum 2013 pembelajaran bahasa Indonesia adalah pembelajaran yang berbasis teks. Dari semua teks tersebut dapat diketahui bahwa akhir dari pembelajaran tentang 
teks adalah siswa mampu memproduksi/menulis teks (Hizati et al., 2018). Dalam pembelajaran menulis menurut (Novelti et al., 2018) keterampilan menulis tidak bisa tercipta begitu saja tanpa melalui proses, keterampilan menulis itu tumbuh dan berkembang akibat adanya proses yang berulang.

Pernyataan keempat adalah penggunaan media pembelajaran membuat materi lebih mudah dipahami. Hasilnya adalah 43,3\% menyatakan sangat setuju, dan 56,7\% menyatakan setuju. Dari hasil survei tersebut penulis dapat menyimpulkan bahwa penggunaan media pembelajaran dapat membuat materi lebih mudah dipahami. Masalah yang sering ditemui dalam pembelajaran menurut (Hartidini \& Ratna, 2018) kurangnya potensi guru untuk membuat pembelajaran bahasa Indonesia menjadi hal yang menarik. Siswa enggan menyampaikan ide mereka baik secara lisan maupun tulis. Oleh karena itu, pemakaian media pembelajaran dapat menumbuhkan minat siswa untuk belajar hal baru dalam materi pembelajaran yang disampaikan oleh guru sehingga dapat dengan mudah dipahami (Nurrita, 2018).

Pernyataan kelima adalah penggunan media pembelajaran membuat proses belajar bahasa Indonesia menjadi lebih menyenangkan. Hasilnya adalah 50\% menyatakan sangat setuju, dan 50\% menyatakan setuju. Dari hasil survei tersebut penulis menyimpulkan bahwa penggunaan media dapat membuat pembelajaran lebih menyenangkan. Sudjana dan Rivai dalam (Nurseto, 2012) media dapat menumbuhkan motivasi belajar siswa karena pengajaran akan lebih menarik perhatian mereka sehingga dapat dipahami siswa dan memungkinkan terjadinya penguasaan Serta pencapaian tujuan pengajaran. Contohnya dalam penelitian oleh Atmazaki dalam (Gustianingsih et al, 2013) mengatakan bahwa teka-teki mampu menciptakan suasana yang menyenangkan.

Pernyataan keenam adalah guru menggunakan media pembelajaran berupa gambar. Hasilnya adalah 13,3\% menyatakan sangat setuju, $80 \%$ menyatakan setuju, dan 6,7\% menyatakan kurang setuju. Dari hasil survei tersebut penulis menyimpulkan bahwa guru telah menggunakan media gambar dalam pelajaran bahasa Indonesia. Pembelajaran dengan menggunakan media bergambar menurut Tarigan dalam (Suhatman Jaya, Syahrul R, 2013) dianjurkan oleh para ahli dan gambar yang kelihatannya diam sebenarnya banyak berkata bagi mereka yang peka dan penuh imajinasi. Oleh karena itu, pemilihan gambar harus tepat, menarik, dan merangsang siswa.

Pernyataan ketujuh adalah guru menggunakan media audiovisual dalam pembelajaran bahasa Indonesia. Hasilnya adalah 10\% menyatakan sangat setuju, 46,7\% menyatakan setuju, dan 43,4\% menyatakan kurang setuju. Dari hasil survei tersebut penulis menyimpulkan bahwa media audiovisual telah digunakan dalam pembelajaran bahasa Indonesia. Manfaat media audiovisual menurut (Mulyani R, Syahrul R, 2018) digunakan untuk merangsang daya pikir siswa dalam menemukan suatu ide pokok sehingga dapat menuliskannya ke dalam sebuah teks. 
Selain itu, media audiovisual dapat melengkapi pengalaman-pengalaman dasar siswa ketika mereka membaca, berdiskusi, berpraktek, dan lain-lain sehingga sangat efektif untuk mempengaruhi dan memanipulasi ide-ide sebelum siswa menuliskannya.

Pernyataan kedelapan adalah guru menggunakan media permainan dalam pembelajaran bahasa Indonesia. Hasilnya adalah 30\% menyatakan sangat setuju, 50\% menyatakan setuju, dan $20 \%$ menyatakan kurang setuju. Berdasarkan hasil survei tersebut penulis dapat menyimpulkan bahwa guru telah menggunakan media permainan dalam pembelajaran bahasa Indonesia. Adapun manfaat menggunakan media permainan menurut (Syofiani et al., 2019) yaitu dengan bermain anak-anak akan berusaha untuk memiliki keinginan dan mencapai keinginannya. Melalui bermain, semua aspek perkembangan anak dapat ditingkatkan. Dengan bermain secara bebas anak dapat berekspresi dan bereksplorasi untuk memperkuat hal-hal yang sudah diketahui dan menemukan hal-hal baru.

Pernyataan kesembilan adalah guru memanfaatkan teknologi dalam pembelajaran bahasa Indonesia. Hasilnya adalah 43,4\% menyatakan sangat setuju, 50\% menyatakan setuju, dan 6,7\% menyatakan kurang setuju. Dari hasil survei tersebut menyatakan bahwa guru telah menggunakan teknologi dalam pembelajaran. Hal ini sejalan dengan pendapat Ivanovic M, Javorský S, Horváth R, dan Goulão M F, Fombona J dalam (Ramadhan et al., 2019) pendidikan harus mencerminkan perubahan aktual dan mempertimbangkan cara-cara yang dapat mendukung tuntutan untuk memberikan kondisi kualitas bagi keberadaan manusia dalam konteks proses transformasi sosial. Pendidikan tidak luput dari transformasi karena di dunia global ketika hal-hal berubah, muncul kebutuhan untuk melanjutkan pendidikan, mendaur ulang dan mengembangkannya untuk memberikan jawaban atas tantangan masa depan.

Pernyataan kesepuluh, literasi media telah direalisasikan dalam pembelajaran bahasa Indonesia. Hasilnya adalah 66,7\% menyatakan sangat setuju, dan 33,3\% menyatakan setuju. Berdasarkan hasil survei tersebut maka penulis dapat menyimpulkan guru telah melakukan literasi media dalam pembelajaran. Hal ini berhubungan dengan pendapat Hobs dalam (Ramadhan et al., 2019) yang menyatakan literasi media merupakan salah satu keterampilan dasar yang harus dimiliki individu di abad 21 dan telah menjadi bagian sentral dan tidak terpisahkan dari kehidupan. Literasi media dapat didefinisikan sebagai penggunaan alat media massa sesuai kebutuhan, mengakses konten dalam alat tersebut, pemahaman, menganalisis dan mengevaluasi pesan secara benar dan sadar.

Dari hasil data di atas dapat disimpulkan bahwa telah digunakan media dalam pembelajaran bahasa Indonesia. Guru telah menggunakan media dalam pembelajaran keterampilan menyimak, berbicara, membaca, dan menulis. Media yang digunakan dalam pembelajaran bahasa Indonesia yaitu media gambar, audiovisual, dan permainan. Media teknologi telah digunakan dalam pembelajaran bahasa Indonesia dan telah direalisasikan literasi 
media dalam pembelajaran. Dari hasil tersebut siswa menyatakan bahwa media memudahkan dalam memahami materi serta membuat pembelajaran menjadi lebih menyenangkan. Namun, terlepas dari itu semua, kita sebagai guru harus mampu memilih media yang tepat guna dalam pembelajaran. Inovasi penggunaan media berbasis teknologi juga dibutuhkan mengingat zaman yang semakin harinya semakin canggih. 


\section{REFERENSI}

Fitri, Y. R, Syahrul, Tamsin, Andria Catri. (2016). Pengaruh Model Pembelajaran Kooperatif Tipe Think Talk Write Berbantuan Media Gambar Berseri Terhadap Keterampilan Menulis Teks Cerpen Siswa Kelas VII SMP Negeri 8 Padang. Jurnal Pendidikan Bahasa dan Sastra Indonesia, 5(2), 548-555.

Handayati, W., Syahrul, R., \& Afnita, A. (2013). Keefektifan Penggunaan Media Lagu dalam Pembelajaran Menulis Puisi Siswa Kelas IX1 SMPN 5 Lubuk Basung. Jurnal Pendidikan Bahasa dan Sastra Indonesia, 1(2), 226-232.

Hartidini, S., Syahrul, R., \& Ratna, E. (2018). Pengaruh strategi pembelajaran inkuiri berbantuan media audiovisual terhadap keterampilan menulis karangan argumentasi siswa kelas $\mathrm{X}$ SMA Negeri 2 Lengayang kabupaten pesisir selatan. Jurnal Pendidikan Bahasa dan Sastra Indonesia, 7(1), 63-69.

Hizati, A., Ramadhan, syahrul, \& Arief, E. (2018). Pengaruh Model Problem Based Learning Berbantuan Media Gambar Berseri Terhadap Keterampilan Menulis Teks Eksplanasi Siswa Kelas Viii Smp Negeri 12 Padang. Pendidikan Bahasa Dan Sastra Indonesia, 7(1), 183-190. https://doi.org/10.31227/osf.io/mh6e3.

Mulyani, R., \& Syahrul, R. (2020). Pengaruh Model Pembelajaran Kooperatif Tipe Think Talk Write (TTW) Berbantuan Media Audiovisual terhadap Keterampilan Menulis Teks Persuasi Siswa Kelas VIII SMP Negeri 8 Padang. Jurnal Pendidikan Bahasa dan Sastra Indonesia, 8(3), 374-382.

Ningsih, A. G., \& Syahrul, R. (2013). Peningkatan Keterampilan Berbicara Melalui Metode Bermain Teka-Teki Siswa Kelas X MAS-TI Tabek Gadang Kabupaten Lima Puluh Kota. Bahasa, Sastra, dan Pembelajaran, 1(3).

Novelti, N., Ramadhan, S., Ermanto, E., \& Agustina, A. (2018). Developing an Instructional Model Assisted Audio Visual Media. 263(Iclle), 111-116. https://doi.org/10.2991/iclle-18.2018.17.

Nurrita, T. (2018). Pengembangan Media Pembelajaran Untuk Meningkatkan Hasil Belajar Siswa. MISYKAT: Jurnal Ilmu-Ilmu Al-Quran, Hadist, Syari'ah Dan Tarbiyah, 3(1), 171. https://doi.org/10.33511/misykat.v3n1.171.

Nurseto, T. (2012). Membuat Media Pembelajaran yang Menarik. Jurnal Ekonomi Dan Pendidikan, 8(1), 19-35. https://doi.org/10.21831/jep.v8i1.706.

Putri, R. D., \& Syahrul, R. (2019). Pengaruh Penggunaan Teknik Think Talk Write (TTW) Terhadap Keterampilan Menulis Teks Fabel Siswa Kelas VII SMP Negeri 31 Padang. Jurnal Pendidikan Bahasa dan Sastra Indonesia, 8(2), 66-73.

Ramadhan, S., Sukma, E., \& Indriyani, V. (2019). Teacher competence in utilizing digital media literacy in education. Journal of Physics: Conference Series, 1339(1). 
https://doi.org/10.1088/1742-6596/1339/1/012111.

Saud, Udin Syaefuddin. (2009). Inovasi Pendidikan. Bandung: Alpabeta.

Suhatman Jaya, Syahrul R, E. (2013). Peningkatan Keterampilan Menulis Puisi Melalui Media Gambar Siswa Kelas X.1 Sma Negeri 2 Kota Sungai Penuh. Journal of Chemical Information and Modeling, 53(9), 1689-1699.

Syofiani, S., Zaim, M., Ramadhan, S., \& Agustina, A. (2019). Peningkatan Keterampilan Berbahasa Siswa Melalui Pemanfaatan Media Teka-Teki Silang: Menciptakan Kelas Yang Menyenangkan. Ta'dib, 21(2), 87. https://doi.org/10.31958/jt.v21i2.1232. 